DOI: https://doi.org/10.32839/2304-5809/2019-5-69-80

UDC 81'42

Liakh Oksana, Nepran Anna

DSEE "Donbas state teachers' training university"

\title{
TERMINOLOGY OF THE ARTICLE AS A SCIENTIFIC TEXT
}

Summary. The authors investigate such form of the scientific text as an article. Scientific article is a type of scientific text that aims at presenting some new result, explaining its significance, and placing it coherently within the existing knowledge. Writing an article scholars should follow some compulsory rules to create a piece of the scientific text. The signs of the article are analysed from the point of view of Lexicology. In the scientific style the most valued attributes are accuracy, precision, clarity, concision, and grace, which is achieved with the help of use of the terminology. There exist a lot of classifications of terms. Authors analyzed several articles of the scientific periodical from the point of view of their vocabulary. The research proved that the amount of terms in the article is about $40 \%$.

Keywords: the article, scientific text, signs, vocabulary, term.

Лях О.В., Непран А.С. ДВНЗ «Донбаський державний педагогічний університет»

\section{ТЕРМІНОЛОГІЧНА ОРГАНІЗАЦІЯ СТАТТІ ЯК НАУКОВОГО ТЕКСТУ}

Анотація. Результати наукових досліджень висвітлюються у формі доповідей, статей, монографій, підручників, патентів, каталогів та інструкцій. Все це є видами наукового тексту, до якого висуваються певні вимоги, серед яких: наявність великої кількості термінів, монологічний характер мовлення, використання вставних слів, посилання на першоджерела, відсутність емоційно-забарвленої лексики, чітка структура тексту, використання складних речень та складних синтаксичних конструкцій, наявність таблиць, графріків, формул та деякі інші. Автори досліджують таку форму наукового тексту як стаття. Наукова стаття - це вид наукового тексту, що презентує нові результати дослідження, їхній аналіз, пояснює їх значущість та визначає їх місце в системі вже існуючих знань. Проаналізовано ознаки статті з точки зору лексикології та стилістики. Виявлено, що словниковий склад статті включає нейтральну, загальнонаукову та вузькоспеціальну лексику. Доведено, що основною ознакою статті як наукового тексту є використання термінів. Терміни поділяються на загальнонаукові та вузькоспеціальні. Також терміни класифікуються як наукові, технічні, промислові, економічні та ін. Терміни представлені такими частинами мови, як іменники, прикметники, діеслова та прислівники. Терміни представлені окремими словами, словосполученнями та сталими виразами. Використовуючи тер-міни, необхідно слідувати певним правилам: використовувати зрозумілі терміни (або давати їх пояснення при першому згадуванні), уникати багатозначних термінів (або уточнювати, яке саме значення мається на увазі), не використовувати одне i те ж слово в різних значеннях. Автори проаналізували декілька статей з наукового періодичного журналу 3 точки зору їх лексики. Дослідження показало, що кількість термінів у статті складає приблизно 40\%, 3 яких 5\% - загальнонаукові терміни, а 15\% - вузькоспеціальні.

Ключові слова: стаття, науковий текст, ознаки, лексика, термін.

The problem of the article. People always have tended to investigate the world, its nature, human's body, language, behavior etc. The results of the research are presented in form of an article, monograph, textbook, patent description, abstract, annotation, documentation, catalogue, manual or instruction. All these are types of the scientific text, to which particular demands are put forward.

The analysis of main researches and publications. The problems connected with the organization of a scientific text, its features were studied by such scholars as I. Kvitko, A. Koval, M. Kozhina, I. Kolegaev, S. Nikitina, N. Razinkina, M. Senkevich, I. Sinitsa, G. Solganik. In particular, they investigated the features of the semantic, structurally-syntactic and pragmatic organization of communicative structural units of scientific vocabulary.

An analysis of these and other scholars' works (G. Vinokur, O. Reformatsky, O. Akhmanova, V. Danilenko, V. Karaban, M. Mostovoi, A. Kovalenko) shows us that the main stylistic feature of the scientific text is accuracy. Accuracy is realized primarily through the terminology. Each branch of science and technology has its own terminology.
The purpose of the article is to define the role of terms in the article as a scientific text.

The main material. The main purpose of a scientific text is a statement of study of a person, community and phenomena of nature, substantiation of hypotheses, proving of the truth of theories, the classification of knowledge, explanation of phenomena, and excitation of a reader's intelligence for their comprehension. Results of researches are made in the form of an article, monograph, textbook, patent description, abstract, annotation, documentation, catalogue, manual or instruction.

"Article is a piece of writing on a particular subject in a newspaper or magazine or on the Internet" $[1$, p. 37]. Also there is the scientific article that is a complete author's work about the results of an original scientific searching (primary scientific article) or is devoted to observing previously published articles connected by common topic (observing scientific article).

What signs allow us to attribute the text in general and article in particular to the scientific style?

For scientific style using international terms is characteristic (management, IT-market, computer, classification). Also in a scientific work it is common 
to use mostly abstract vocabulary (genius, phenomenon, feeling) but not concrete (glass, flower, clock).

The lexical contain of scientific style is characterized by relative homogeneity and isolation and it is shown in decrease of using synonyms. The content of a scientific text increases not because of using different words but because of repeating one and the same word.

A scientific text shouldn't contain vocabulary with colloquial colouring be-cause of its appraisal. An appraisal in scientific works is used to explain an author's idea or to draw someone's attention and it has rational nature.

Scientific speech is characterized by accuracy and consistency of a thought, consistency and objectivity of its narration. In order to make logical structure of an article more visual it's good to use different introductory words and phrases like first of all, in addition, simultaneously, summing up and other. But you shouldn't begin every sentence with it.

Also in order to make narration of a material more logical in scientific speech it is recommended to use complex sentences, introductory words and word-groups, participial constructions and so on. For scientific style the high informational saturation is usual. Texts of this style are characterized by an author's detachment and objectivity of expounded of information. It is expressed by using impersonal constructions (for example, it's known that, presumably, there is a reason to believe and so on). Also scientific texts may contain different formulas, diagrams, symbols, tables etc. Practically any scientific text may contain graphical information; it is one of the features of scientific style.

In scientific articles three major groups of vocabulary are used. They are common, general scientific and highly specialized terms. The first group of words is the most popular and widely used in the articles (it occupies nearly $51 \%$ of all words). The second type is used to describe some processes and phenomena in different branches of science (the amount of such words is equal to $32 \%$ ). Words of the last group are less frequently presented in articles (mostly in the field of linguistics, mathematics and biology).

To widen the information we should tell more about all groups of vocabulary used in a scientific article.

Common lexis as we have said is the largest part a text in any article or utterance. They are used to denote vital notions that are clear to everyone. It is possible to say that they are neutral because in scientific articles the denotational meaning is used (sign, dream, problem).

General scientific vocabulary is less frequently used because it requires some knowledge in different spheres. The function of it is to present a phenomenon or a subject (phenomena, classification, irrational).

The highly specialized terminological component of a scientific article is sometimes called the nuclear of scientific style. So terms are the representatives of definitive and nominative functions and they give the concrete idea of an object or phenomenon (affix, abbreviation, equivalent).

Dealing with a scientific article one should use them carefully. In order to be understood correctly some rules of using terminology are the next:
- contextual match (the word that is used should have only one meaning);

- lexical match (the meaning of the element of a term should correspond to the notion it possesses);

- consistency (the possibility to show relations between the named notion and the notion connected with it);

- rational compactness (removing words and other elements that possess non-distinctive features of a notion);

- derivative component (creating new terms with the help of word formation methods);

- language correctness (adherence to the rules of word formation and word-of-mouth that corresponds to the structure of a given language).

The articles devoted to the terminological issues understand a term as a word or a word combination that does only nominative function, the function of naming of the special concept and naming a special subject or phenomenon. A term of any branch of knowledge expresses special professional, scientific or technical notion.

According to the usage in different spheres of professional communication there three groups of terms exist. There are general scientific, intersectoral and highly specialized terms.

General scientific lexis is commonly used in different scientific disciplines and it expresses special notions of a wide section that are sorted with objects, phenomena, processes, properties and so on in different areas of the studying reality (reaction, experiment, to progress).

To the second group of terms intersectoral or professional lexis is referred. It is functionally oriented to the narrower sphere of usage. Such terminology possesses the highest degree of thematic productivity (physical terms like energy should know specialists in optics and radio physics (energy, metal, symbol)).

The third group of words consists of specialized vocabulary expressing notions of a separate discipline (mathematics, medicine). The philologist Kozhina underlines that specialized terminology has a strong functional stylistic coloring. Such terms in unusual sphere are not only difficult to understand but also it leads to rejection of the fact that it is used in this area (hydrogen, cardiology, syntax).

There are also a lot of other classifications based on different features of terms.

The content classification (the classification by subject name) proposes division of terms according to the special spheres. There are, for example, scientific (structure, to absorb), technical (television, to translate), industrial (manufacturer, to import), economic (audit, to globalize) and other areas. Such a scheme forms the list of rubrics that are included into this classification. So the classification by subject name inside separate spheres of knowledge is the most detailed term classification.

The classification of terms-words is done according to the word morphological structure. There are such terms as:

- non-derivative (type, model);

- derivative (decoding, stylistic);

- compound (atmosphere);

- abbreviation (UN, UNESCO).

The morphological classification may be presented by nouns (generation, regulation, combina- 
tion), adjectives (additional, pragmatic, semantic, cooperative) and verbs terms (appear, consider, occur, devote). Adjectives take great part in term formation because they are important elements of composed terms.

According to the semantic structure there are free word-groups, set expressions and phraseological combinations. According to the morphological type of a primary word there are word-groups-nouns, word-groups-adjectives and word-groups-verbs.

There are also less frequently used classifications, for example according to the sphere of usage (universal, unique and author's terms) and so on.

Thus, due to the classifications the conceptual structure of terms is clearly demonstrated.

The author of a scientific article using terms should try to be unambiguously understood. The author should follow the following rules:

- use only the most understandable and univocal terms;

- ignore a word that has two meanings without defining which of them will be used;

- not use some words in their different meanings.

We analyzed several articles of the scientific periodical "Molodyj Vchenyj" [3] from the point of view of their vocabulary. The analysis showed the presence of the following layers of vocabulary in the articles:

- common (to cover, never, surprise, negative, to use, to point, interesting, wide, to help etc.), which is about $60 \%$ of all vocabulary;

- general scientific terminology (function generation, combination, re-search, analysis, infor- mation, aim, object, term, aspect etc.) $-25 \%$ of all vocabulary;

- highly specialized terminology (tag question, linguist, speech act com-municative tactics, pragmatic meanings, irregular forms, communicative situation, language etc.) - 15\% of all vocabulary.

This information gives us the image of a science article and its contain.

Conclusions. Scientific article is a type of scientific text that aims at presenting some new result, explaining its significance, and placing it coherently within the existing knowledge. Writing an article scholars should follow some compulsory rules to create a piece of the scientific text:

- plenty of scientific terminology;

- use of abstract words;

- use of scientific phraseology, proof terminological word-combinations;

- reference to the original sources;

- absence of authorial individual manner and emotionally-expressive vocabulary;

- presence of clear structure of the text (successive division to pieces, points, subitems, indentions from application of digital or designated by a letter numeration);

- use verbal forms, more often impersonal, generalized or indefinite, as a rule, Present tense, that define certain phenomena and facts;

- presence of tables;

- monologue character of the text.

So, in the scientific style the most valued attributes are accuracy, precision, clarity, concision, and grace [2], which is achieved with the help of use of the terminology.

\section{References:}

1. American English 2000. Cambridge Dictionary of American English. Cambridge UP. 2000.

2. Chris A. Mack How to Write a Good Scientific Paper. SPIE PRESS. Bel-lingham, Washington, USA. 2018. 124 p.

3. «Molodyi Vchenyi». Archive journal numbers. URL: http://molodyvcheny.in.ua/ua/archive/ (accessed: 10.04.2019). 